\title{
Conferencia Anual de la Association for Medical Education in Europe (AMEE) en Málaga: novedades
}

\author{
A. Wojtczak
}

La Conferencia de la Association for Medical Education in Europe (AMEE 2009) en Málaga fue organizada conjuntamente con la Sociedad Española de Educación Médica (SEDEM), que celebró simultáneamente su XIX Congreso. Tuvo lugar en un moderno centro de convenciones que disponía de confortables instalaciones para ambos congresos. Una novedad excepcional para una conferencia monolingüe como la AMEE fue que las sesiones plenarias se traducían simultáneamente al castellano y además se desarrollaron sesiones en dicha lengua. En esta ocasión vale la pena recordar que en 1970, cuando se fundó la SEDEM, durante la celebración en Madrid del 'Seminario sobre métodos de enseñanza', organizado conjuntamente con la Oficina Regional de la Organización Mundial de la Salud de Copenhague, se decidió crear la AMEE. Este año, la AMEE y la SEDEM han organizado conjuntamente el foro mundial para los educadores médicos, que ha congregado a más de 2.300 participantes procedentes de 86 países de todos los continentes. Un aspecto muy estimulante es que más del $50 \%$ de los participantes lo hacían por primera vez y han podido conocer, a través de sus colegas, los beneficios educativos de la conferencia. Esto es un signo de la creciente popularidad de esta conferencia anual, fundamentada en el reconocimiento de la calidad de sus actividades. Debe señalarse el gran número de talleres dedicados a diferentes aspectos de la educación médica, llegándose por primera vez a 75 , lo cual parece indicar que el participante quiere aprender aspectos educativos prácticos y no solamente escuchar las comunicaciones orales. La validez de esta observación queda corroborada por el hecho de que los cursos de Essential Skills in Medical Education (ESME) sobre diferentes aspectos de habilidades docentes, así como sobre una amplia variedad de métodos de evaluación en educación médica (ECMEA), habilidades básicas para la investigación en educación médica (RESME) o principios básicos y métodos para identificar, seleccionar y utilizar métodos para estimular la educación médica (ESTME), contaron con una gran participación a pesar de suponer un esfuerzo económico adicional.

También las sesiones de paneles desempeñan un papel cada vez más importante no sólo por su rápido crecimiento, sino por el incremento de su calidad. Las sesiones de paneles atraen paulatinamente a más participantes que se implican de forma activa en la discusión de los diferentes temas presentados, lo cual no puede producirse durante las sesiones plenarias o las sesiones en grupos grandes.

Este desarrollo puede considerarse extremadamente satisfactorio y estimulante para los directivos de la AMEE, ya que indica que los participantes quieren regresar con un conocimiento práctico y con habilidades para utilizarlas en su entorno. Es también un signo del creciente interés en la introducción de innovaciones en la educación médica.

Una sesión muy concurrida fue la denominada 'sesión de orientación', recientemente introducida y que se desarrolla antes de la ceremonia inaugural con el objetivo de dar a los nuevos participantes una visión del pasado y del presente de la AMEE, e informarlos del programa, indicando
Exdirector del International Institute for Medical Education (IME)

Expresidente de la Association for Medical Education in Europe (AMEE)

E-mail wojtczak@cmkp.edu.pl 
las principales actividades. Esta importante asistencia confirma la necesidad de facilitar una información que permita a los asistentes encontrar su camino entre los centenares de actividades de las diferentes conferencias.

Finalmente, debemos mencionar que los premios instituidos por la AMEE para reconocer la trayectoria de aquellos que han contribuido al desarrollo de la asociación y de la educación médica fueron otorgados a los anteriores presidentes de la asociación, el profesor Henry Walton (1972-1986) y el profesor Albert Oriol Bosch (1990-1993). Por su parte, el Premio Antonio Gallego, instituido por la SEDEM en 2005 en memoria de uno de los grandes pioneros de la educación médica en España, con el fin de reconocer la excelencia de una carrera profesional en educación médica, se otorgó al profesor Andrzej Wojtczak, en reconocimiento a su dilatada colaboración con los educadores médicos españoles.

Estoy seguro de que los asistentes a la Conferencia de la AMEE de Málaga regresaron a su país no sólo con valiosas experiencias profesionales, nuevos contactos y renovadas amistades, sino también con el recuerdo de una estancia memorable en Andalucía.

\section{The Association for Medical Education in Europe (AMEE) Malaga Annual Conference-what's new?}

The Malaga AMEE Conference was organized in cooperation the Spanish Association for Medical Education (SEDEM) that held simultaneously their XIX meeting. It was organized in the modern Congress Center that provided very comfortable facilities for both meetings. What was exceptional for AMEE normally monolingual conference that plenary sessions were simultaneous translated to Spanish and there were some sessions in Spanish. On this occasion it is worthwhile to remind that in 1970, when SEDEM had been just established, during organized jointly with the World Health Organization Regional Office in Copenhagen the 'Seminar on teaching methods in medicine' in $\mathrm{Ma}$ drid the decision was taken about establishment of the Association for Medical Education in Europe. Now they come together to organize jointly the world forum for medical educators that attracted over 2300 participants from 86 countries and all continents. What is encouraging is fact that over $50 \%$ of attendees were coming for the first time and they have learnt about the educational merits of a conference from their colleagues. It is a good sing of growing popularity of this annual meeting, based on the recognition of quality of conference activities. What is worthwhile to note was a great number of Workshops devoted to the different aspects of medical education, which number for the first time reached 75 , and what seems to indicate that attendee wants to learn some educational aspects practically and not only listen to presentations. Validity of this observation can support also the fact that very well attended were also the Essential Skills in Medical Education (ESME) courses dealing with different aspects of teaching skills such as a wide variety of assessment methods in medical education (ECMEA), basic skills in carrying out research in medical education (RESME), or some essential principles and methods for identifying, selecting and utilizing technology to enhance medical education (ESTME) even it involves additional financial charges.

Also the posters sessions are playing an increasing role not only because every year fast increasing number of poster presentations, but because the high quality of these presentations. The poster sessions are attracting more and more conference attendees being actively involved in the discussion on the presented topics, what is lacking during the plenary of big group sessions presentations.

This development can be extremely satisfying and encouraging for AMEE executives, indicating that the participants of the conference wants to take back to home country a practical knowledge and skills to use it in the home. It is also a sing a fast growing interest in the introducing of the innovations to medical education processes.

The very well attended session was a one introduced recently so call 'orientation session' organized before opening conference to give to newcomers a glimpse of AMEE past and presence and to providing them with programme information with an indication on various activities, what indicates on the need of such briefing to enable attendees to find their way in hundreds of different conference activities.

Finally, worthwhile to mention that the newly established the AMEE 'Lifetime achievement price' for those who greatly contributed to the development of the organization and medical education was handed to the past AMEE Presidents-Professor Henry Walton (1972-1986) and Professor Al- 
berto Oriol Bosch (1990-1993). On the other hand, created by the SEDEM in 2005 the Antonio Gallego Award in memory of one of the great pioneers' of medical education in Spain that to be presented to persons who has developed excellence in a professional career in the field of medical education, this year went to Professor Andrzej Wojtczak in rec- ognition of his longstanding cooperation with the Spanish educators.

I am quite sure that participants of the AMEE Malaga Conference took back home not only the valuable professional experiences, new communication lines and refreshed friendships but also took back a memorable time spend in Andalusia. 